\title{
Molecular characterization of cajá, Spondias mombin (Anacardiaceae), by RAPD markers
}

\author{
A.T.B. Lima ${ }^{1}$, V.A.B. de Souza ${ }^{1}$, R.L.F. Gomes ${ }^{2}$ and P.S.C. Lima ${ }^{1}$ \\ ${ }^{1}$ Embrapa Meio-Norte, Teresina, PI, Brasil \\ ${ }^{2}$ Departamento de Fitotecnia, Centro de Ciências Agrárias, \\ Universidade Federal do Piauí, \\ Campus Universitário Ministro Petrônio Portella, Teresina, PI, Brasil \\ Corresponding author: P.S.C. Lima \\ E-mail: sarmanho@cpamn.embrapa.br/paulosarmanho@yahoo.com.br
}

Genet. Mol. Res. 10 (4): 2893-2904 (2011)

Received December 15, 2010

Accepted September 10, 2011

Published November 25, 2011

DOI http://dx.doi.org/10.4238/2011.November.25.1

\begin{abstract}
The arboreal species Spondias mombin L. (Anacardiaceae) is widely distributed in Brazil, where the fruits, known by the common name of cajá, are an important commercial commodity. We evaluated genetic variability among 32 cajá accessions of the Germplasm Collection of Embrapa Meio-Norte using RAPD technique. Reaction conditions for efficient RAPD amplifications were optimized in preliminary tests, and primers were selected from a set designed by the University of British Columbia on the basis of high levels of polymorphism and adequate band resolution. The 21 primers employed in the final analysis produced 145 fragments, $79 \%$ of which were polymorphic. Based on the RAPD data, a dendrogram was constructed using the unweighted pair group method with arithmetic mean clustering technique. The 32 cajá accessions were classified into three main groups with a mean genetic similarity of $68.8 \%$. Group I comprised 26 accessions ( $74.1 \%$ similarity), and group II included five accessions (74.0\% similarity), while group III consisted of one accession (BGC 06), which exhibited the lowest similarity coefficients. Accessions BGC 06 and BGC 31 were the most unrelated and, hence, most suitable for initial crossings in order to obtain
\end{abstract}


high levels of segregation. We concluded, based on the repeatability and reproducibility tests, that the RAPD technique is reliable and efficient for revealing the genetic diversity of cajá accessions, which will be useful for genetic improvement programs.

Key words: Cajá; Genetic variability; Plant improvement

\section{INTRODUCTION}

The genus Spondias (family Anacardiaceae) comprises a number of economically important trees, including Spondias mombin L., S. tuberosa Arr. Câm. (umbu), S. purpurea L. (ciriguela), S. dulcis Park. (cajarana or cajá-mango), and Spondias sp (umbu-cajá and umbuguela) (Sacramento et al., 2008). S. mombin originates from tropical America where it is known as jobo in Mexico, yellow mombin in the Caribbean islands and gully plum in Jamaica. The species is distributed throughout Brazil where the exotic fruits are known by a wide variety of regional names including taperebá in the Amazon, small cajá in the southeast, cajámirim in the south, or simply cajá in the northeast (Bosco et al., 2000). Cajá fruits are rich in vitamins $\mathrm{A}, \mathrm{B} 1, \mathrm{~B} 2$, and $\mathrm{C}$, calcium, phosphorus, potassium, carotenoids, and tannins, and can be eaten raw or in the form of pulp, nectar, sorbet, jam, or liqueur. The wood of cajá is employed in the furniture manufacturing industry, while the bark and leaves are used in popular medicine (Sacramento and Souza, 2000).

Although no statistical data are available for cajá, the fruits are considered to be of great importance in the northeastern region of Brazil because of the growing demand for the products derived from them and the increasing interest in improving cultivation of the species. In the State of Piauí, however, cajá cultivation is currently restricted to small farmers and is generally carried out in a rudimentary manner without the application of advanced technology (Leal, 2005).

Knowledge regarding the genetic variability of any species is an essential prerequisite for its preservation and for success in breeding programs. In the case of cajá, a high genetic variability among cultivars has been confirmed by a number of studies involving morphological (Soares et al., 2006; Mendonça et al., 2008), isoenzyme (Gois et al., 2009) and molecular (Silva, 2009) markers.

Recently, studies in plant breeding have focused on the search for molecular markers linked to different economic traits, which would allow the indirect selection of desirable characteristics in early segregating generations. According to Oliveira et al. (2007), the use of such markers has advanced the development of genetics and breeding mainly by offering the possibility of access to the genotype rather than just the phenotype, thus allowing the study of genetic mapping, genetic diversity, phylogeny and indirect marker-assisted selection.

Among the various molecular techniques based on the polymerase chain reaction (PCR), random amplified polymorphic DNA (RAPD) markers are advantageous because they can detect polymorphisms in a very straightforward manner. Furthermore, RAPD markers can be used in studies concerning genetic divergence since they are efficient in distinguishing minimal differences between individuals, populations and species (Brammer, 2000). Intraspecific characterization and evaluation of the genetic variability of accessions with the aid of molecular markers facilitate the selection of the most suitable accessions for cultivation and/ or plant improvement, and reduce the time spent on this stage of the process. 
The aim of the present study was to determine the genetic variability among the cajá accessions in the Germplasm Collection of Embrapa Meio-Norte using RAPD markers in order to select genotypes suitable for use in commercial cultivation and in future breeding projects.

\section{MATERIAL AND METHODS}

\section{Plant material and extraction of genomic DNA}

Thirty-two cajá accessions were available in the Germplasm Collection of Embrapa Meio-Norte, and these originated from Teresina, Altos, Eliseu Martins, Demerval Lobão, and Itaueira in the State of Piauí, and Timon in the State of Maranhão (Table 1). Young healthy leaves were collected from each accession, wrapped separately in paper towels, placed in plastic bags and transported to the laboratory in a box filled with ice. DNA extraction was carried out immediately with the aid of Invisorb Spin Plant Mini kits (Invitek, Berlin, Germany) or DNeasy Plant Mini kits (Qiagen, Valencia, CA, USA), according to manufacturer instructions. Sample leaves $(100 \mathrm{mg})$ were macerated separately in a Precellys ${ }^{\circledR} 24$ tissue homogenizer and grinder (Bertin, Montigny-le-Bretonneux, France) using 2-mL tubes with five 3-mm glass beads and buffers from the appropriate extraction kit. Quantification of genomic DNA was performed by comparison with $\lambda$ DNA standards (50,100 and $150 \mathrm{ng}$ ) following electrophoresis on $0.8 \%$ agarose gel in Tris-borate-EDTA ( $0.5 \mathrm{X}$ TBE) buffer and staining with SYBR ${ }^{\circledR}$ Safe DNA Gel Stain (10,000X; Invitrogen, Carlsbad, CA, USA). The quality of DNA was determined with the aid of a Nanodrop (Wilmington, DE, USA) model 2000 spectrophotometer using $2-\mu \mathrm{L}$ aliquots of the extracts. DNA samples were diluted in Tris-EDTA (TE) buffer to a final concentration of $15 \mathrm{ng} / \mu \mathrm{L}$ and stored in the freezer at $-20^{\circ} \mathrm{C}$ until required for RAPD reactions.

Table 1. Origins of the accessions of cajá (Spondias mombin L.) in the Germplasm Collection of Embrapa Meio-Norte.

\begin{tabular}{ll}
\hline Origin & Accessions \\
\hline Timon (MA) & $B G C 02, B G C$ 03, BGC 13 \\
Itaueira (PI) & $B G C 17$ \\
Eliseu Martins (PI) & $B G C 08$ \\
Altos (PI) & $B G C 04, B G C 05, B G C$ 06 \\
Teresina (PI) & $B G C 01, B G C 07, B G C 09, B G C 10, B G C 11, B G C 12, B G C 14, B G C 15, B G C 16, B G C 18, B G C 19$, \\
& $B G C 20, B G C 21, B G C 22, B G C 23, B G C 24, B G C 25, B G C 26, B G C 27, B G C 28, B G C 29, B G C 30$ \\
Demerval Lobão (PI) & $B G C 31, B G C 32$ \\
\hline MA = State of Maranhão; PI = State of Piauí.
\end{tabular}

\section{RAPD reactions}

PCR amplifications were carried out in 0.2-mL microtubes using a Veriti 96-Well Thermal Cycler (Applied Biosystems, Foster City, CA, USA) according to the general protocol of Williams et al. (1990). However, in order to optimize the PCR assays, preliminary tests were performed under various reaction conditions that included $\mathrm{MgCl}_{2}$ concentrations of 1.5, $2.0,2.5$, or $3.0 \mathrm{mM}$, dNTP concentrations of $0.25,0.40,0.50$, or $0.75 \mathrm{mM}$, annealing temperatures of $32^{\circ}$ or $35^{\circ} \mathrm{C}$, and 40 or 45 reaction cycles. Optimized reaction mixtures comprised $1 \mathrm{X}$

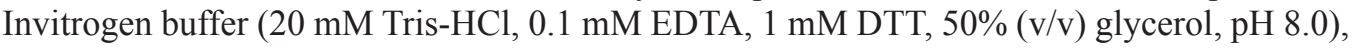
$3.0 \mathrm{mM} \mathrm{MgCl}$ (Invitrogen), $0.75 \mathrm{mM}$ dNTP (Invitrogen), $1 \mathrm{U}$ Taq DNA polymerase (CenbiotEnzimas, Porto Alegre, RS, Brazil), $0.2 \mu \mathrm{M}$ primer, $1 \mu \mathrm{L}$ DNA template $(\sim 15 \mathrm{ng})$ and ultrapure 
distilled water to a final volume of $20 \mu \mathrm{L}$. Optimized reaction conditions were: initial denaturation step at $92^{\circ} \mathrm{C}$ for $1 \mathrm{~min}, 45$ cycles comprising denaturation at $92^{\circ} \mathrm{C}$ for $1 \mathrm{~min}$, annealing at $35^{\circ} \mathrm{C}$ for $1 \mathrm{~min}$ and extension at $72^{\circ} \mathrm{C}$ for $2 \mathrm{~min}$, and a final extension step at $72^{\circ} \mathrm{C}$ for 5 min. In these assays, primers A10 and M03 (with melting temperatures of $22.26^{\circ}$ and $26.36^{\circ} \mathrm{C}$, respectively) were employed in order to assess their behavior under the reaction conditions.

With the purpose of selecting the most suitable primers for the subsequent RAPD reactions, DNA samples from cajá accessions BGC 17 and BGC 29 were amplified using 100 primers developed by the University of British Columbia. Twenty-one primers (Table 2) were chosen on the basis of resolution and high levels of polymorphism, and these were used in amplification reactions involving DNA samples from each of the 32 cajá accessions. For each assay, amplicons were separated by electrophoresis on $1.5 \%$ agarose gel in $0.5 \mathrm{X} \mathrm{TBE}$ at $100 \mathrm{~V}$ for $4 \mathrm{~h}$. Gels were stained with SYBR Safe DNA Gel Stain (10,000X), visualized under a UV transilluminator and photographed. DNA ladders of $100 \mathrm{bp}$ and $1 \mathrm{~kb}$ (Invitrogen) were used as molecular weight markers.

\begin{tabular}{|c|c|c|c|}
\hline \multirow[t]{2}{*}{ Primer } & \multirow[t]{2}{*}{ Size of amplified fragments (bp) } & \multicolumn{2}{|c|}{ Numbers of fragments } \\
\hline & & Total & Polymorphic \\
\hline OPA03 & $600-2036$ & 10 & 8 \\
\hline OPA05 & $600-2036$ & 7 & 5 \\
\hline OPA08 & $506-3054$ & 8 & 6 \\
\hline OPA 10 & $600-3054$ & 7 & 7 \\
\hline OPA14 & $320-2036$ & 5 & 5 \\
\hline OPF02 & $700-2036$ & 8 & 8 \\
\hline OPF03 & $1100-1500$ & 3 & 2 \\
\hline OPF04 & $300-1636$ & 9 & 7 \\
\hline OPF15 & $300-3054$ & 9 & 8 \\
\hline OPG02 & $350-3054$ & 8 & 5 \\
\hline OPG08 & $390-3000$ & 10 & 9 \\
\hline OPG17 & $510-4072$ & 9 & 8 \\
\hline OPG18 & $870-3000$ & 7 & 3 \\
\hline OPL01 & $1100-2100$ & 6 & 3 \\
\hline OPL03 & $1100-1500$ & 4 & 3 \\
\hline OPL14 & $600-1500$ & 8 & 7 \\
\hline OPM07 & $1150-4072$ & 8 & 7 \\
\hline OPN14 & $1100-1300$ & 2 & 1 \\
\hline OPN16 & $650-3054$ & 5 & 4 \\
\hline OPN18 & $900-2100$ & 5 & 3 \\
\hline OPT12 & $700-2100$ & 7 & 6 \\
\hline Total & & 145 & 115 \\
\hline
\end{tabular}

\section{Data analysis}

Initially, a visual examination of the gel photographs was performed in order to determine the number of polymorphic bands generated by each primer, taking into account the resolution and degree of amplification. Only bands with medium and strong intensities were included in the investigation. Each band was considered as representing a single character, and a binary matrix was created in which 1 indicated the presence of the marker and 0 its absence. This matrix was used to estimate the genetic similarity between the cajá accessions using Jaccard coefficients, and on this basis a dendrogram was constructed using the unweighted pair group method with arithmetic average (UPGMA) clustering technique. The cophenetic 
correlation coefficient (r) was calculated from the similarity matrix and the dendrogram. The bootstrap confidence index was also evaluated from the binary matrix of amplified fragments generating a dendrogram from 1000 permutations. Analyses were performed with the aid of the PAST version 1.34 program (Hammer et al., 2001).

\section{Repeatability and reproducibility of RAPD amplifications}

Three different tests using primer OPG17 were carried out to determine the reliability of the RAPD method: (i) repeatability - amplification reactions involving DNA samples from each of the 32 cajá accessions were repeated exactly as described above using Cenbiot-Enzimas Taq DNA polymerase; (ii) reproducibility with different thermocyclers - the amplifications outlined in (i) were performed using a Techne ${ }^{\circledR}$ Endurance TC412 Thermal Cycler (Bibby Scientific, Stone, UK), and (iii) reproducibility with different Taq DNA polymerases - the amplifications outlined in (i) were performed using Invitrogen Taq DNA polymerase.

\section{RESULTS}

Extraction of the 32 cajá accessions provided genomic DNA that was suitable for RAPD amplifications. The absorbance ratio at 260 and $280 \mathrm{~nm}$ of the extracted DNA varied from 1.24 to 1.96 (mean of 1.72), while the concentrations of the DNA solutions were in the range 15 to $150 \mathrm{ng} / \mu \mathrm{L}$ (mean of $63.1 \mathrm{ng} / \mu \mathrm{L}$ ). The conditions selected for the PCRs, namely $3.0 \mathrm{mM} \mathrm{MgCl}, 0.75 \mathrm{mM} \mathrm{dNTP}, 35^{\circ} \mathrm{C}$ annealing temperature and 45 cycles, generated bands of good definition and with high resolution. The 21 primers selected for the RAPD analyses produced 145 fragments, of which $115(79.3 \%)$ were polymorphic (Table 3). The average number of bands produced per primer was 6.8 , with an average of 5.4 bands per primer being polymorphic, and the size of the amplicons varied between 300 and $4072 \mathrm{bp}$. Figure 1 shows the degree of polymorphism of the RAPD bands generated by primers OPG08 (Panel A) and OPF15 (Panel B).

The dendrogram (Figure 2) indicating the relationships among the 32 cajá accessions showed a mean genetic similarity of $68.8 \%$. The accessions could be separated into three main clusters. Group I comprised 26 accessions and had a mean similarity of $74.1 \%(62.2-85.2 \%)$, and group II included five accessions with a mean similarity of $74.0 \%(61.4-85.2 \%)$, while group III consisted of a single accession (BGC 06), which displayed the lowest similarity value $(45.5 \%)$ of all accessions. The highest similarity $(85.2 \%)$ was determined for the accessions BGC 13 and BGC 14, which had been collected in the States of Maranhão and Piauí, respectively. The reliability of the data and the consistency of the nodes are demonstrated by the bootstrap values shown in Figure 2, and by the cophenetic correlation coefficient of $92.4 \%$. Comparison of the band patterns of the 32 accessions generated by RAPD amplifications with those obtained in the first validation test employing primer OPG17 indicates that repeatability was $100 \%$ (Figure $3 \mathrm{~A}$ and B). The reproducibility of the band patterns generated in the second test in which two different thermal cyclers were used was also highly satisfactory $(91.7 \%$; Figure $3 \mathrm{~B}$ and $\mathrm{C}$ ). In the third test, in which amplification reactions were carried out using Taq DNA polymerases from Cenbiot-Enzimas and Invitrogen were compared, reproducibility was estimated at $83.3 \%$ (Figure $3 \mathrm{~A}$ and $\mathrm{D}$ ). 


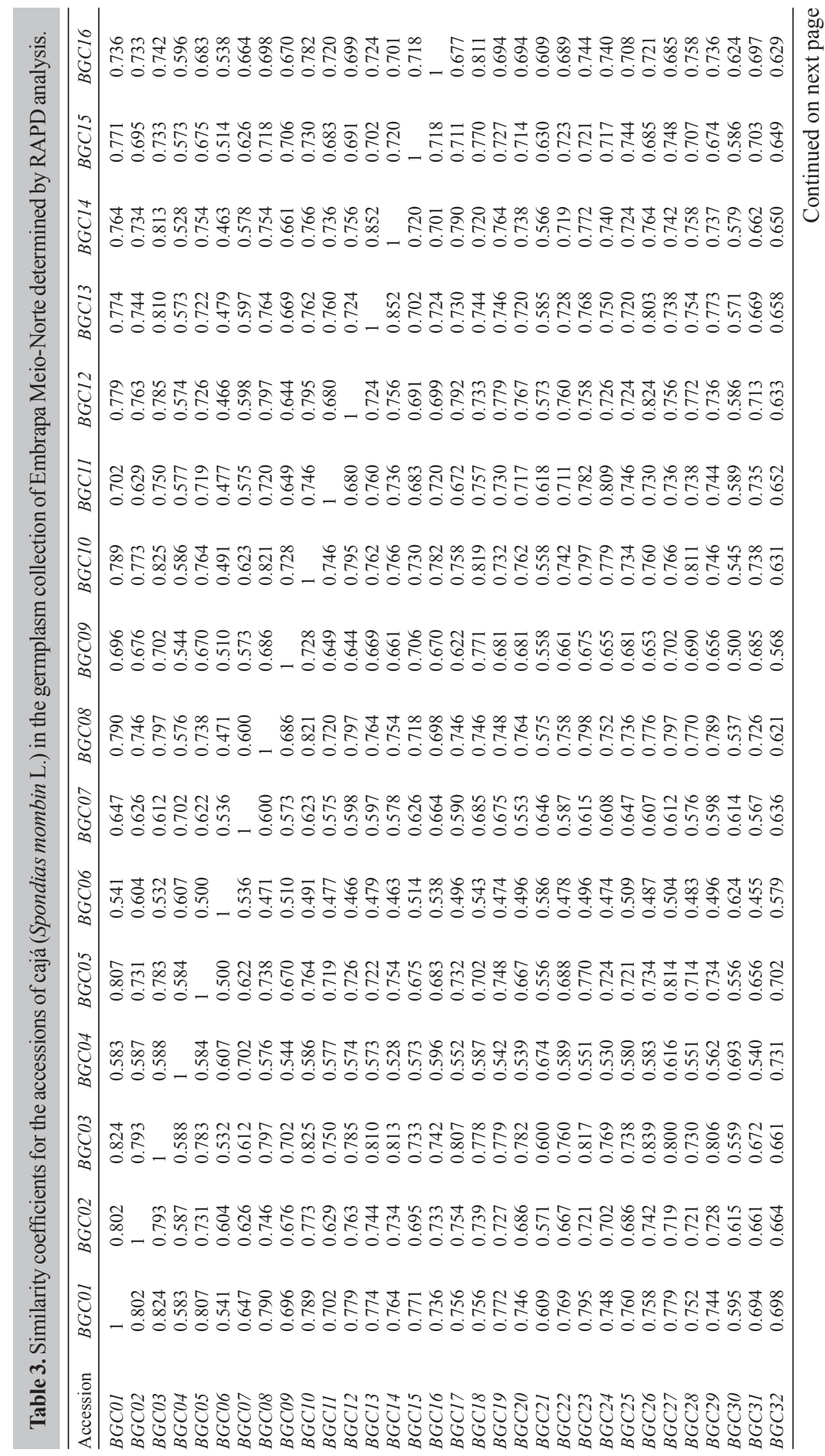




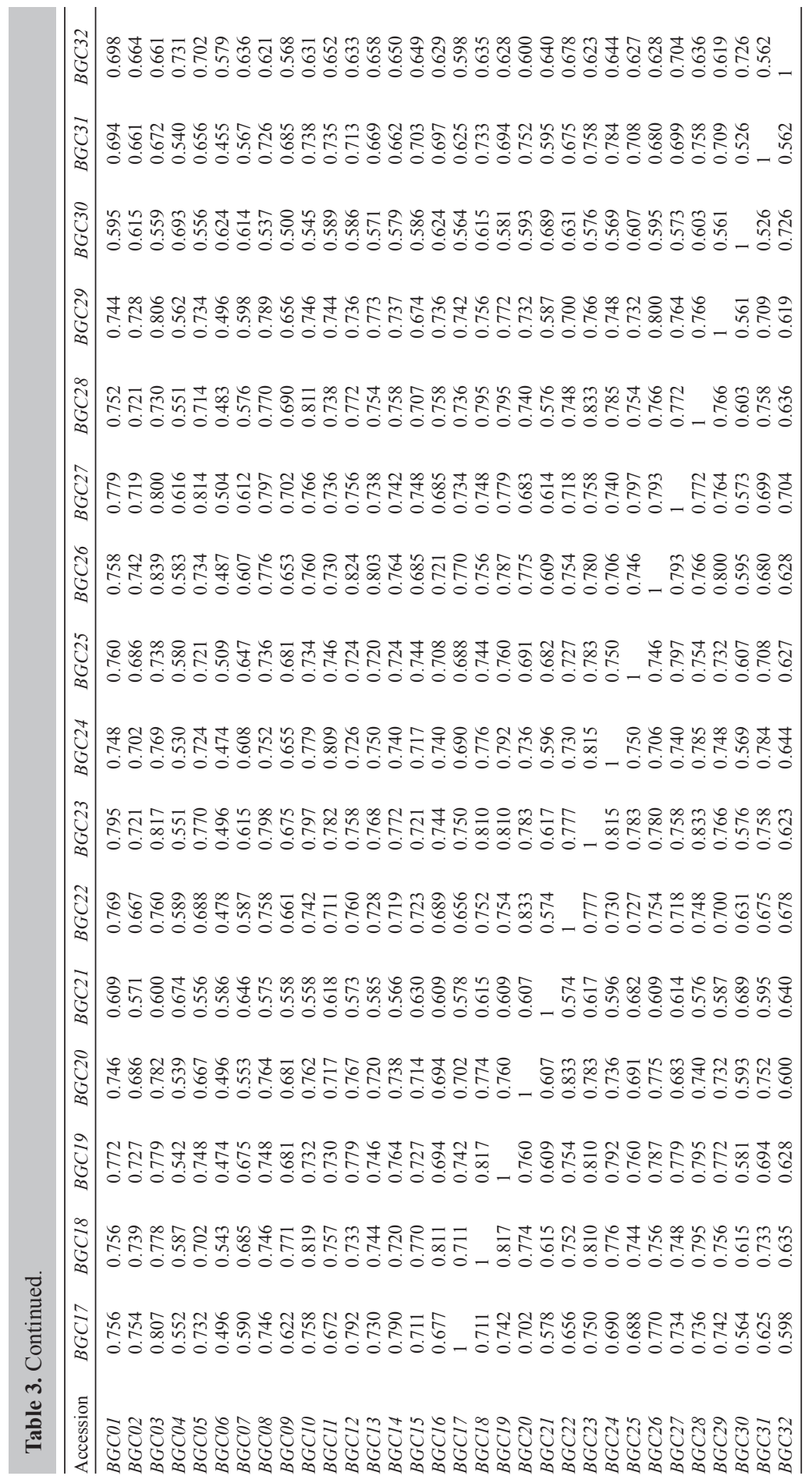




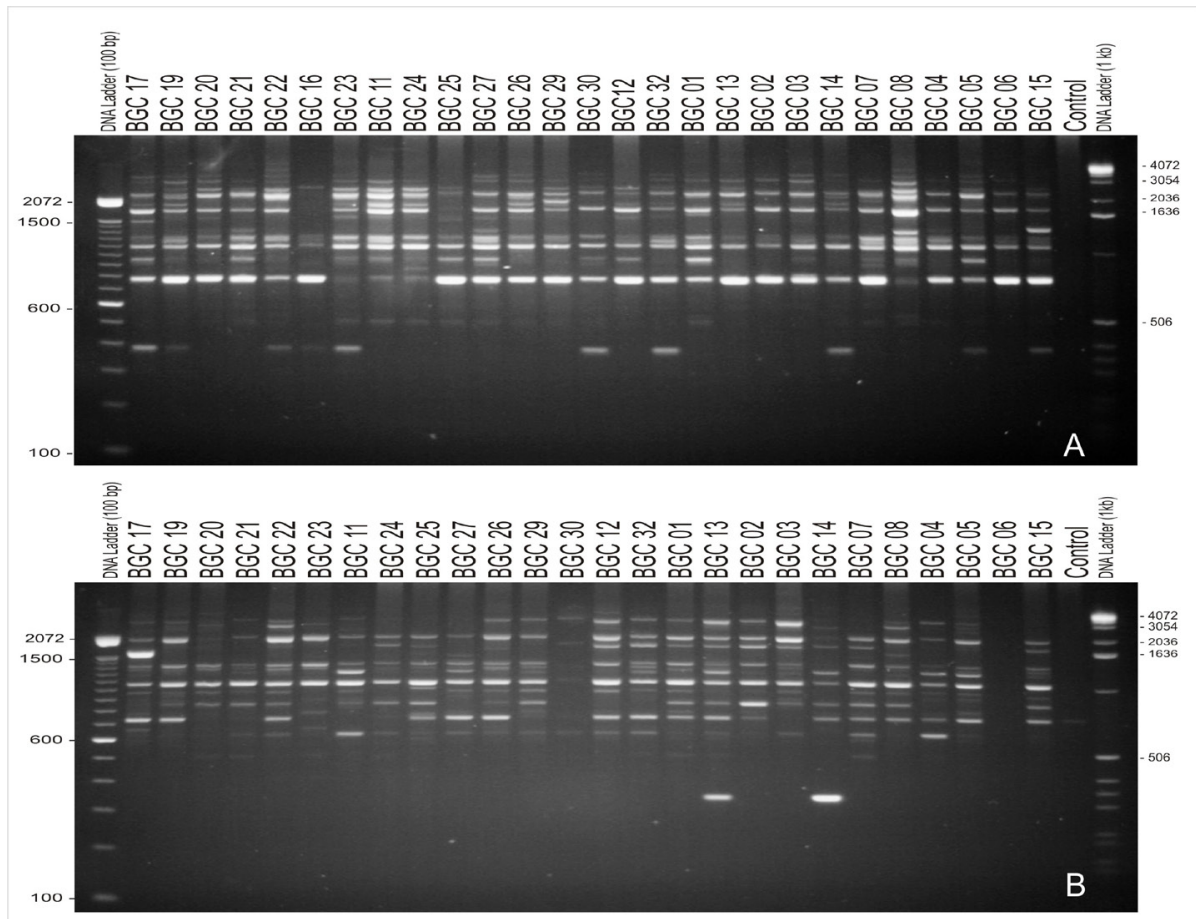

Figure 1. Electrophoretic profiles of RAPD amplifications of DNA samples from 27 accessions of cajá (Spondias mambin L.) generated using primers OPG08 (Panel A) and profiles from 26 accessions generated using primers OPF15 (Panel B).

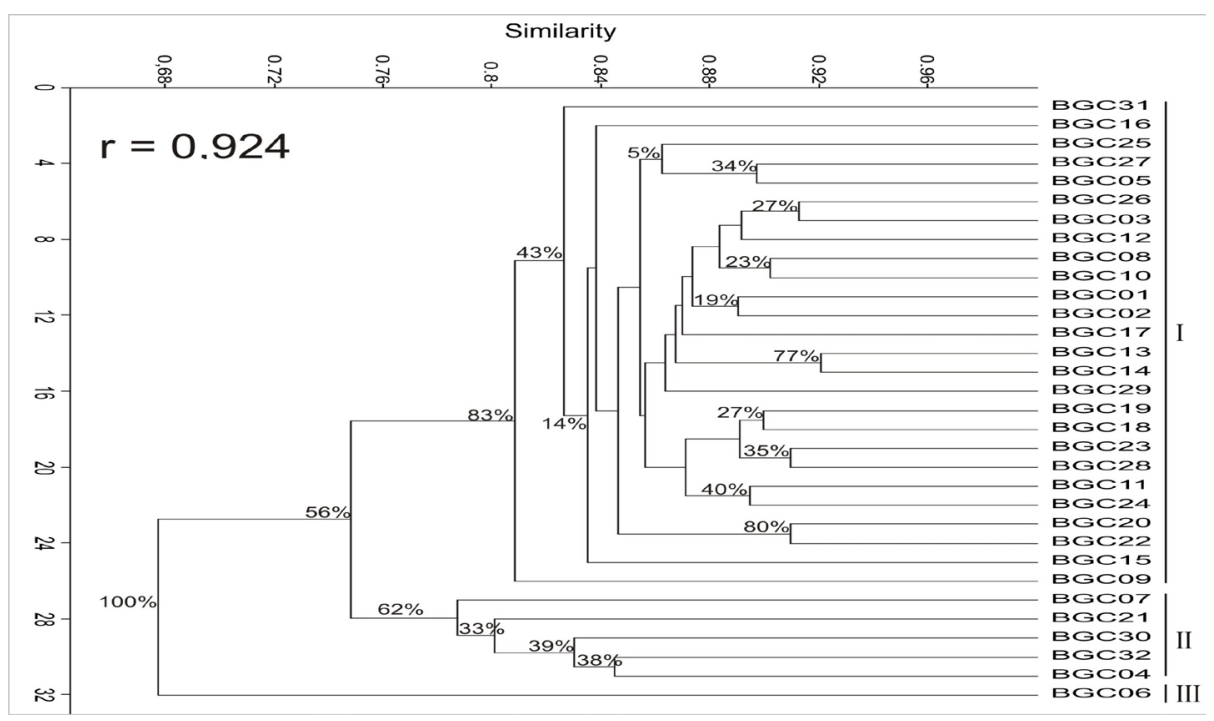

Figure 2. UPGMA dendrogram based on 21 RAPD polymorphic markers showing similarity relationships between 32 accessions of cajá (Spondias mombin L.). 


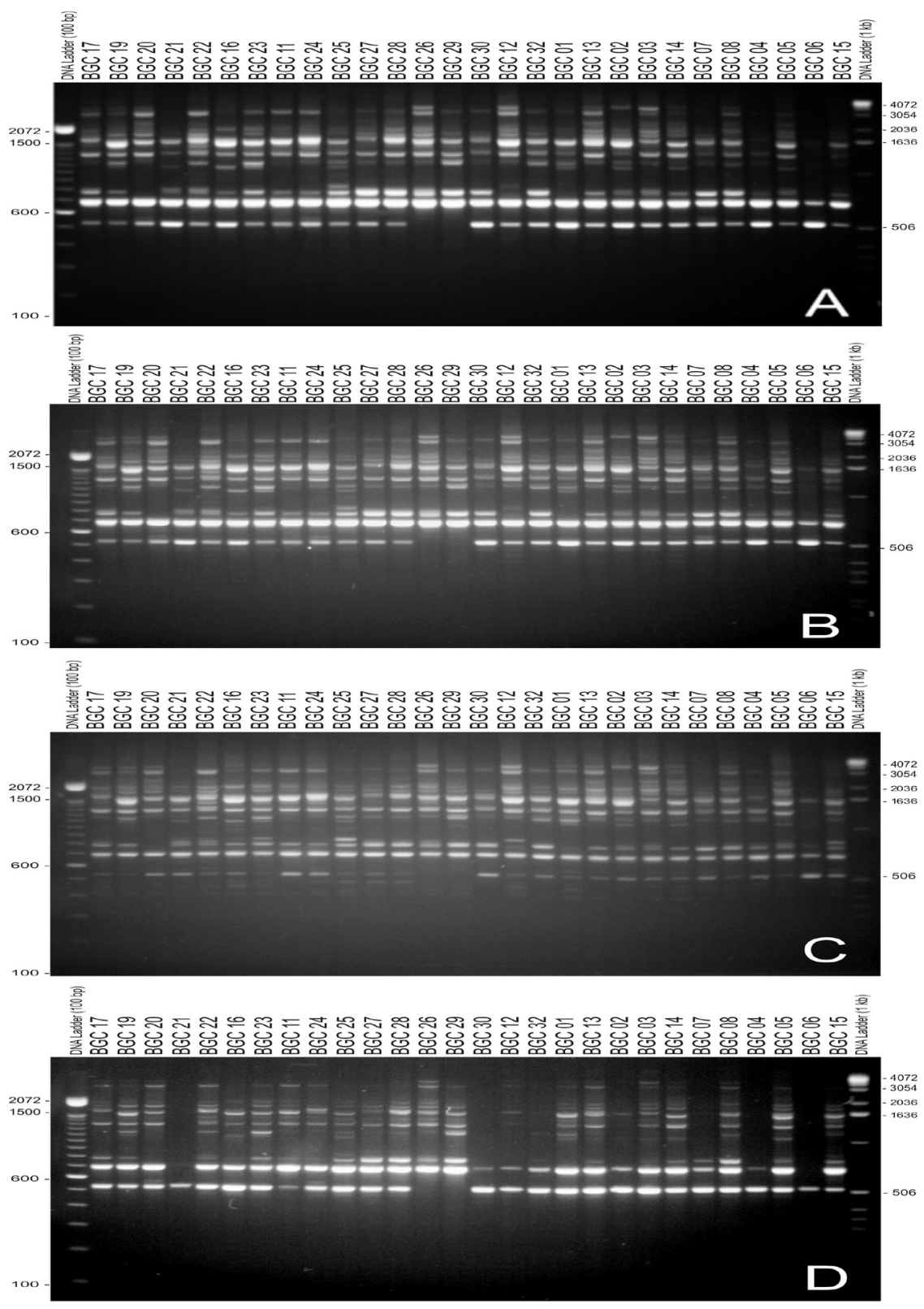

Figure 3. Electrophoretic profiles of RAPD amplifications of DNA samples from 28 accessions of cajá (Spondias mombin L.) generated using primer OPG17 and showing: (i) repeatability of band pattern using the same brand of Taq DNA polymerase (Panels A and B); (ii) reproducibility of band pattern using a different thermal cycler (in Panel C a Techne ${ }^{\circledR}$ Endurance TC412 Thermal Cycler was employed), and (iii) reproducibility of band pattern using a different brand of Taq DNA polymerase (in Panel D an Invitrogen polymerase was employed). The amplification conditions were identical in all experiments, and Cenbiot-Enzimas Taq DNA polymerase and Veriti 96 Well Thermal Cycler were employed throughout, unless stated otherwise. 


\section{DISCUSSION}

According to Freitas (2005), 15-mer oligonucleotide primers require annealing temperatures between $40^{\circ}$ and $50^{\circ} \mathrm{C}$, whereas lower annealing temperatures (around $35^{\circ} \mathrm{C}$ ) are recommended for the shorter primers, generally used in the RAPD technique. In the present study, however, the primers used in the preliminary tests (A10 and M03) did not influence the selection of the annealing temperature used in the experiments.

The number of bands produced by RAPD primers appears to be independent of the size of the genome, with an average number of five bands per reaction (Ferreira and Grattapaglia, 1998). Hence, the average number of bands per primer (6.8) obtained in the present study was considered to be satisfactory, especially since the degree of polymorphism of the fragments was high.

The location from which the accessions had been collected had no influence on their position within the genotypic groups (Figure 2). For example, accessions BGC 04, BGC 05 and BGC 06 from Altos (State of Piauí) showed an average similarity of $56.4 \%$, although they were classified in different groups. In a similar manner, accessions BGC 31 and BGC 32 from Demerval Lobão (State of Piauí) exhibited 56.2\% similarity but were classified in different groups. Such results indicate that these accessions derived from different progenitors and that there is large genetic diversity within the species $S$. mombin. Interestingly, the accessions collected in Teresina and Timon (States of Piauí and Maranhão, respectively) displayed average genetic similarities equivalent to 70.3 and $78.2 \%$, respectively, and the great majority were uniformly distributed within group I.

Based on an estimate of the genetic diversity of 12 cajá accessions using inter-simple sequence repeat (ISSR) markers, Silva (2009) claimed that there was no correlation between genetic similarity and the origin of the accessions. However, the mean similarity between these accessions was much lower $(27.45 \%)$ than that reported herein, indicating that the diversity among the cajá accessions of the Germplasm Collection of Embrapa Meio-Norte is somewhat restricted. This view is supported by the RAPD marker study of Gois et al. (2008) in which 17 cajá plants collected in the State of Sergipe exhibited a genetic similarity of $46.77 \%$ (range 21-78\%). Since S. mombin is a native species that is still in the process of domestication, significant divergence between accessions would be expected. It is likely that the level of homogeneity observed in the germplasm analyzed in the present study was a result of selection during sampling. Moreover, growth of the accessions was carried out via vegetative propagation (grafting), and thus, there is variation between individuals of the same accession. Nevertheless, the values of average similarity $(68.8 \%)$ and similarity between most accessions indicated there is variability in the germplasm analyzed. In this context, Mendonça et al. (2008) carried out a physicochemical analysis (weight of fruits, weight of stones, amount of pulp, total soluble solids, total titratable acidity, etc.) of the fruits from 18 of the Embrapa cajá accessions and verified the occurrence of genetic diversity within the collection. Based on the physicochemical characteristics of the fruits, Soares et al. (2006) also demonstrated the presence of diversity among 14 cajá genotypes distributed in the municipality of Teresina, and stressed the possibility of selecting superior individuals for direct use in the improvement of commercial orchards. Genetic diversity in populations of S. mombin has also been observed in studies involving isoenzyme markers in which the observed heterozygosity was greater than that expected (Gois et al., 2009; Silva et al., 2009). 
According to some researchers (Oliveira et al., 2007), one of the main limitations of the RAPD technique is the low level of repeatability of the band pattern observed when amplification reactions have not been optimized. In the present study, repeatability and reproducibility tests revealed that the amplification reactions were carried out under adequate and optimized conditions that generated consistent RAPD bands. High levels of repeatability in RAPD loci have also been reported for the frog Physalaemus cuvieri (85-99\%; Telles, 2005) and for a Cerrado plant Tibouchina papyrus (85\%; Ramos et al., 2008). Some studies have shown that different brands of Taq DNA polymerase can produce dissimilar results in PCRs (Evangelopoulos et al., 2001; Verweij et al., 2004; Al-Soud et al., 2005), and in several cases enhancers such as bovine serum albumin, casein, formamide, and polyvinylpolypyrrolidone are required to facilitate amplification. Moreover, some types of Taq DNA polymerase are more susceptible to inhibition than others, and this may cause differences in the band patterns obtained (Wilson, 1997).

The results presented herein reveal that genetic variability is present in the cajá accessions in the Germplasm Collection of Embrapa Meio-Norte and can be exploited in future breeding programs. The accessions BGC 06 and BGC 31 were the most unrelated and, therefore, the most suitable for initial crossings in order to obtain high levels of segregation. It is concluded from the results of the repeatability and reproducibility tests that the RAPD technique is reliable and efficient in revealing the genetic diversity of cajá accessions.

\section{REFERENCES}

Al-Soud WA, Ouis IS, Li DQ, Ljungh S, et al. (2005). Characterization of the PCR inhibitory effect of bile to optimize real-time PCR detection of Helicobacter species. FEMS Immunol. Med. Microbiol. 44: 177-182.

Bosco J, Soares KT, Aguiar-Filho SP and Barros RV (2000). A Cultura da Cajazeira. Empresa Estadual de Pesquisa Agropecuária da Paraíba, João Pessoa.

Brammer SP (2000). Marcadores Moleculares: Princípios Básicos e Uso em Programas de Melhoramento Genético Vegetal. Embrapa Trigo, Passo Fundo. Available at [http://www.cnpt.embrapa.br/biblio/p_do03.htm]. Accessed August 10, 2010.

Evangelopoulos A, Legakis N and Vakalis N (2001). Microscopy, PCR and ELISA applied to the epidemiology of amoebiasis in Greece. Parasitol. Int. 50: 185-189.

Ferreira ME and Grattapaglia D (1998). Introdução ao Uso de Marcadores Moleculares em Análise Genética. $1^{\text {a }}$ ed. Embrapa-Cenargen, Brasília.

Freitas PD (2005). Estudos de Diversidade Genética em Camarões Utilizando Marcadores Moleculares. Manual Prático. Volume 1. Universidade Federal de São Carlos, São Carlos. Available at [http://www.shrimp.ufscar.br/docs_pubs/ GUIA.pdf]. Accessed August 10, 2010.

Gois IB, Silva-Mann R, Ferreira RA and Ferreira RA (2008). Diversidade Genética de Indivíduos de Spondias lutea L., por Marcadores RAPD, Procedentes do Baixo São Francisco Sergipano. In: Livro de Resumos do XVIII Encontro de Iniciação Científica e IV Encontro de Pós-Graduação da Universidade Federal de Sergipe, Aracaju. Available at [http://www.posgrap.ufs.br/down/Livro_Resumos_18EIC_4EPG.pdf]. Accessed August 10, 2010.

Gois IB, Silva-Mann R and Ferreira RA (2009). Diversidade genética de Spondias lutea L. em uma população do baixo São Francisco sergipano, por meio de isoenzimas. Sci. For. Piracicaba 37: 55-60.

Hammer Ø, Harper DAT and Ryan PD (2001). PAST: Paleontological Statistics Software Package for education and Data Analysis. Palaeontol. Electron. 4: 1-9. Available at [http://palaeo-electronica.org/2001_1/past/past.pdf]. Accessed August 10, 2010.

Leal AF (2005). Condições do Extrativismo e Aproveitamento das Frutas Nativas da Microrregião de Teresina - Piauí. Master's thesis, Universidade Federal do Piauí, Teresina.

Mendonça RU, Moura CFH, Alves RE and Figueredo RW (2008). Caracterização Física de Frutos da Cajazeira (Spondias mombin L.) Oriundos da Região Meio-Norte do Brasil. In: Anais do XX Congresso Brasileiro de Fruticultura and LIV Annual Meeting of the Interamerican Society for Tropical Horticulture, Vitória, 4.

Oliveira ACB, Caixeta ET, Zambolim EM and Zambolim L (2007). Aplicação Técnica de Marcadores Moleculares no 
Melhoramento de Plantas. Documentos IAC No. 81. Instituto Agronômico de Campinas, Campinas. Available at [http://www.iac.sp.gov.br/BTonline/Documentos_IAC_81.pdf]. Accessed August 10, 2010.

Ramos JR, Telles MP, Diniz-Filho JA, Soares TN, et al. (2008). Optimizing reproducibility evaluation for random amplified polymorphic DNA markers. Genet. Mol. Res. 7: 1384-1391.

Sacramento CK and Souza FX (2000). Cajá (Spondias mobin L.), Série Frutas Nativas. $4^{a}$ ed. Funep, Jaboticabal.

Sacramento CK, Ahnert D, Barreto WS and Farias JC (2008). Recursos Genéticos e Melhoramento de Spondias na Bahia Cajazeira, Cirigueleira e Cajaraneira. In: Spondias no Brasil: Umbu, Cajá e Espécies Afins (Lederman IE, Lira-Júnior JS and Silva-Júnior JF, eds.). IPA/UFRPE, Recife, 54-62.

Silva CJD (2009). Caracterização Genética de Cajazeiras (Spondias mombin L.) (Anacardiaceae) por Meio de Marcadores Moleculares. Master's thesis, Universidade Federal Rural de Pernambuco, Recife.

Silva EF, Martins LSS and Oliveira VR (2009). Diversity and genetic structure in cajá tree (Spondias mombin L.) populations in northeastern Brazil. Rev. Bras. Frutic. 31: 171-181.

Soares EB, Gomes RLF, Carneiro JGM and Nascimento FN (2006). Característica física e química de frutos de cajazeira. Rev. Bras. Frutic. 28: 518-519.

Telles MPC (2005). Estrutura Genética Populacional de Physalaemus cuvieri Fitzinger, 1986 (Anura: Leptodactylidae) e Padrões de Ocupação Humana no Estado de Goiás. Doctoral thesis, Universidade Federal de Goiás, Goiânia.

Verweij JJ, Blange RA, Templeton K, Schinkel J, et al. (2004). Simultaneous detection of Entamoeba histolytica, Giardia lamblia, and Cryptosporidium parvum in fecal samples by using multiplex real-time PCR J. Clin. Microbiol. 42: 1220-1223.

Williams JG, Kubelik AR, Livak KJ, Rafalski JA, et al. (1990). DNA polymorphisms amplified by arbitrary primers are useful as genetic markers. Nucleic Acids Res. 18: 6531-6535.

Wilson IG (1997). Inhibition and facilitation of nucleic acid amplification. Appl. Environ. Microbiol. 63: 3741-3751. 